\title{
Increasing Rice Yield through Targeting Genetic Potentials by Rice Types
}

\author{
S M H A Rabbi ${ }^{*}$, P L Biswas ${ }^{2}$, E S M H Rashid ${ }^{3}$, K M Iftekharuddaula $^{4}$, N M F Rahman ${ }^{5}$, M S \\ Rahman $^{6}$, M A R Sarkar7, M A A Mamun ${ }^{5}$, M U Salam ${ }^{8}$ and M S Kabir ${ }^{9}$
}

\begin{abstract}
Bangladesh needs an average rough rice yield of $9.11 \mathrm{tha}^{-1}$ by 2050 which can not be achieved equally across all the geographic regions since the country has various 'rice types' with varying yield potentials. This paper focuses on strategic innovations for reaching the yield target by refining rice types. Based on rice ecosystems and the pressing needs, we divided rice areas of Bangladesh in 17 different types. We estimated year-wise land areas and allocated achievable yield targets for each of the rice types. Finally, we compared the target yields and the yields of top-yielding rice varieties in Bangladesh by 2020 across the rice types to understand the current status of our varietal improvement programmes. We sorted out how much improvement is needed in each rice types. Among the rice types, cold-tolerant (Northern and Western) was sorted out as the most potential area of rice yield improvement where rice varieties will be released having a yield advantage of $4.04 \mathrm{t} \mathrm{ha}^{-1}$ by 2050. The chronology of next priority areas for high yielding variety development and their target yield advantages in $\mathrm{t} \mathrm{ha}^{-1}$ are saline Boro (4.03), Favourable Boro (long duration) (4), cold-tolerant (Haor) (3.83), tidal submergence (3.8), Healthier rice (Boro) (3.58), Favourable Boro (short duration) (3.33), Healthier rice (Aman) (3.3), Favourable Aman (3.23), Flash flood (3.09), upland rice (2.89), Saline Aman (2.8), Healthier rice (Aus) (2.53), Premium quality rice (2.53), drought (2.38), T. Aus (2.05) and deepwater. Combined genetic interventions like population improvement through cyclic breeding, genomic selection, marker-assisted selection, genome editing, genetic transformation, germplasm utilization through genome-wide association study and phenomics, and development of super hybrid rice are being used in the country to attain yield target for different rice types.
\end{abstract}

Key words: Rice types, plant breeding, biotechnology, germplasm, hybrid rice.

\section{INTRODUCTION}

Rice production in Bangladesh has been phenomenal in the last 45 years; the country is now producing surplus rice (Kabir et al., 2015). However, more rice will be required to produce in the years to come to feed the increasing population. An estimate says 44.6 MT of clean rice will be required in 2050 (Kabir et al., 2015) compared with 35.3 MT that has been produced in 2015 (Kabir et al., 2015). Unfortunately, this possesses a great challenge to meet the future demand for rice domestically.

Rice areas in Bangladesh, standing at 11.28 Mha in 2015 and will be 11.87, 12.10,
12.04, and 11.07 Mha respectively, in 2020, 2030, 2040, and 2050 (Kabir et al., 2020). Improving continued genetic potential through increasing yield would be the base for meeting the country's rice demand.

Accordingly, a minimum of an average rough rice yield target of $9.11 \mathrm{t} \mathrm{ha}^{-1}$ has been set for 2050 (Kabir et al., 2015). However, this target can not be achieved equally across all the geographic regions of Bangladesh. Because, the country has various 'rice types' based on specific ecosystems, and also due to the pressing 'needs'. All these 'rice types' have different situation-specific yield potentials and area coverages.

\footnotetext{
${ }^{1}$ Biotechnology Division, Bangladesh Rice Research Institute (BRRI), Gazipur-1701, Bangladesh;래ybrid Rice Division, BRRI, Gazipur-1701, Bangladesh; ${ }^{3}$ Genetic Resource and Seed Division, BRRI, Gazipur-1701, Bangladesh; ${ }^{4}$ Plant Breeding Division, BRRI, Gazipur-1701, Bangladesh; ${ }^{5}$ Agricultural Statistics Division, BRRI, Gazipur-1701, Bangladesh;'Plant Physiology Division, BRRI, Gazipur-1701, Bangladesh;7Agricultural Economics Division, BRRI, Gazipur-1701, Bangladesh; ${ }^{8}$ Freelancer International Consultant (Agricultural Systems), Bangladesh; ${ }^{9}$ Director General, BRRI, Gazipur1701, Bangladesh.

*Corresponding author's E-mail: smhisam.rabbi@gmail.com (S M H A Rabbi)
} 
With the above background, this article undertook three specific objectives in relation to achieving the future target genetic yield potential (GYP) in Bangladesh: (i) presentation of the changing status of target GYP over the decades, (ii) highlighting the scenarios of challenges achieving target GYP across rice types, and (iii) development and mapping the action plans for three decades on achieving target GYP by genetic interventions being carried out by the Bangladesh Rice Research Institute (BRRI). It may be noted that BRRI is the prime institute for rice research in the country and BRRI released 106 inbred and hybrid rice varieties. Additionally, this paper incorporates ongoing and future actions of rice breeding, biotechnology, hybrid breeding and germplasm interventions of BRRI toward achieving GYP of rice in Bangladesh.

\section{MATERIALS AND METHODS}

We define the following rice types of Bangladesh based on ecological adaptation, and/or product need to better estimate the changing status of target GYP over the decades.

\section{Rice types}

Favourable Boro (Short duration). We define Favourable Boro (short duration) rice cultivars grown in the Boro season (dry season) in Favourable environments (no potential abiotic stress excluding natural calamities) having a life span within 145 days.

Favourable Boro (Long duration). Favourable Boro (Long duration) rice type covers rice cultivars of favourable Boro environments (no potential abiotic stress excluding natural calamities) but the life duration of such cultivars is more than 145 days.

Saline (Boro). Saline (Boro) rice cultivars are cultivated in the saline prone coastal part of Bangladesh in the Boro season.

Cold tolerant (Haor). A haor in the north-eastern part of Bangladesh, physically is a bowl-shaped shallow depression. It receives surface run-off water during monsoon and becomes vast stretches of turbulent water for several months. This vast stretch becomes suitable for rice cultivation in the Boro season for a short period. Shortduration Boro rice varieties having cold tolerance both at vegetative (active tillering stage) and the reproductive phases (pollen mother cell division stage) are ideal for this region.

Cold tolerant (Northern and western). Rice varieties with cold tolerance at the vegetative phase (seedling and active tillering stage) are suitable for Boro cultivation in the northern and western regions of Bangladesh.

Healthier rice (Boro). After getting food sufficiency, Bangladesh is now moving towards producing quality food. As a part of this effort, BRRI is releasing rice varieties rich in micronutrients like iron, zinc, etc. We name thesemicronutrient and vitamin-rich rice varieties cultivated in the Boro season as healthier rice (Boro).

Favourable Aman. Favourable Aman (FA) is the rain-fed Aman rice ecosystem seemingly having no adverse climatic and soil conditions. This type of rice has a maximum acreage in Bangladesh.

Saline (Aman). Saline (Aman) rice is cultivated in the coastal belt of Bangladesh during Aman season.

Flash flood. The northern regions of Bangladesh often experience a flash flood in the monsoon requiring rice varieties having submergence tolerance for 2-3 weeks during the vegetative phase. Rice varieties having this property fall under flash flood rice.

Drought. The north-western part of Bangladesh is drought-prone and rain-fed rice in those areas face terminal drought frequently. Therefore, drought-tolerant Aman 
rice cultivars are preferably grown in those areas which are regarded as drought rice.

Tidal submergence. The tidal submergence ecosystem lies in the southern region which is tidal prone and one of the major unFavourable ecosystems of Bangladesh. This ecosystem includes both saline and non-saline conditions. Mostly $\mathrm{T}$. Aman rice is grown in the non-saline areas. Rice with taller seedling height can survive under tidal submergence and hence rice varieties with similar traits are categorized under this type.

Deepwater. Medium-level elongation capacity and lodging tolerance are crucial for surviving in the unfavourable semi-deepwater areas of Manikganj, Cumilla, and Faridpur. Rice cultivars grown in these areas are deepwater rice.

Healthier rice (Aman). We name micronutrient and vitamin-rich rice varieties cultivated in Aman season as healthier rice (Aman).

Upland. Upland rice is also a short-duration (March to July) rainfed ecosystem where seeds are broadcasted in the main rice fields.

T-Aus. T-Aus is a partially rain-fed shortduration rice (April to August) where seedlings are transplanted in main rice fields.

Healthier rice (Aus). We name micronutrient and vitamin-rich rice varieties cultivated in the Aus season as healthier rice (Aus).

Premium quality rice. Grain aroma, fine texture, and tastiness provide premium prices in the rice market home and abroad. Therefore, rice with such attributes falls under premium quality rice $(\mathrm{PQR})$.

In order to estimate changing status of target GYP over the decades, first we had to estimate the changing land allocation for rice types over the decades.

\section{Changing status of land allocations for rice types over the decades}

The total rice cultivated areas of 2015 (BBS, 2018) and the projected year-wise rice land (Kabir et al., 2020) data were taken as baseline. We got different ecosystem areas (Pandey and Bhandari, 2018) and stress-prone arable land areas in Bangladesh (Iftekharuddaula et al., 2011; Karim et al., 1990). However, none of the data sources could combine the complete rice ecosystems of Bangladesh. Also, we needed to allocate lands for quality rice and nutrient-rich rice. Altogether we partitioned the total rice cultivated areas into 17 different rice types. We needed to split the land areas for different rice ecosystems into the 17 rice types logically.

\section{Changing status of target GYP over the decades}

National paddy yield targets for rice types over different years were determined based on the required yield increment rate. Potential yields for 2015 of rice types were used as base yields. The base yields of 2015 of rice types were assumed considering mainly potential yields of available varieties of those rice types areas. We considered a national annual rice yield increase of $1.39,1.36,1.24$, and 1.30 percent from 2015 to 2020, 2021 to 2030, 2031 to 2040 and 2041 to 2050 respectively (Kabir et al., 2020).

\section{Challenges achieving target GYP across rice types}

To determine rice types having bigger challenges, firstly we relied on the best existing varieties for rice types by 2020. Then we compared their yields with the target yields in 2050 for the respective rice types. We calculated the difference between the target yields of rice varieties in 2050 with the highest potential yields of rice varieties so far released by 2020 according to rice types. When a rice type had suitable varieties both under inbred and hybrid categories, we assumed $80 \%$ adaptation for an inbred variety and 20\% adaptation for a hybrid for potential yield 
calculation of that rice type. Then, we ranked the priority rice improvement areas based on the magnitude of the differences between the target yield by 2050 and the highest potential yields of rice varieties by 2020 .

\section{Development and mapping the action plans} for three decades on achieving target GYP

To achieve the set GYP targets for 17 rice types in the three decades through to 2050, this paper has mapped an action plan accounting for ongoing and potential tools on rice breeding, biotechnology, hybrid breeding, and germplasm enhancement. The action plan includes research and development in respective fields, which were worked out through expert consultation.

\section{RESULTS AND DISCUSSION}

\section{Changing status of land allocations for rice types over the decades}

The total cultivated rice areas in 2015 were 11.28 Mha. Our projected rice land will be $11.87,12.10,12.04$, and 11.07 Mha respectively, in 2020, 2030, 2040, and 2050 (Kabir et al., 2020). Rice area acreage for FA is the largest and will remain so over the years. On the contrary healthier rice (Aus) covers minimal coverage (Table 1$)$.

Table 1. Area coverage of rice types (Mha) in Bangladesh during 2015-2050.

\begin{tabular}{llllll}
\hline Rice type & 2015 & 2020 & 2030 & 2040 & 2050 \\
\hline Favourable Boro (short duration) & 1.06 & 1.09 & 1.06 & 1.00 & 0.87 \\
Favourable Boro (Long duration) & 1.16 & 1.19 & 1.16 & 1.10 & 0.96 \\
Saline Boro & 0.59 & 0.61 & 0.59 & 0.57 & 0.49 \\
Cold tolerant (Haor) & 0.59 & 0.61 & 0.59 & 0.57 & 0.49 \\
Cold tolerant (Northern and Western) & 0.40 & 0.41 & 0.40 & 0.38 & 0.33 \\
Healthier rice (Boro) & 0.20 & 0.20 & 0.21 & 0.19 & 0.17 \\
Favourable Aman & 2.32 & 2.49 & 2.64 & 2.74 & 2.62 \\
Saline Aman & 0.72 & 0.77 & 0.82 & 0.85 & 0.81 \\
Flash flood & 0.72 & 0.77 & 0.82 & 0.85 & 0.81 \\
Drought & 0.72 & 0.77 & 0.82 & 0.85 & 0.81 \\
Tidal submergence & 0.52 & 0.56 & 0.59 & 0.61 & 0.59 \\
Deepwater & 0.52 & 0.56 & 0.59 & 0.61 & 0.59 \\
Healthier rice (Aman) & 0.22 & 0.24 & 0.25 & 0.26 & 0.25 \\
Upland rice & 0.29 & 0.29 & 0.29 & 0.27 & 0.24 \\
T. Aus & 0.77 & 0.80 & 0.78 & 0.73 & 0.64 \\
Healthier rice (Aus) & 0.08 & 0.09 & 0.08 & 0.07 & 0.07 \\
Premium quality rice & 0.40 & 0.41 & 0.40 & 0.38 & 0.33 \\
Total land & 11.28 & 11.87 & 12.10 & 12.04 & 11.07 \\
\hline & & & & \\
\end{tabular}


Changing status of target GYP over the decades

The base yield of Favourable Boro (long duration) rice in 2015 was assumed maximum and yield targets over the years will remain maximum following the year-wise required increment rate. On the other hand, base yield and projected yield targets are the lowest in deepwater rice since the base yield of deepwater rice in 2015 was minimum among the rice types (Table 2).

\section{Challenges achieving target GYP across rice types}

We have a major challenge in cold-tolerant (Northern and western) rice type since our target is to reach the yield of $10.04 \mathrm{t} \mathrm{ha}^{-1}$ by 2050 in this rice type and to date, we have the highest yielder, BR18 with a potential yield of $6 \mathrm{t} \mathrm{ha}^{-1}$ (Table 3) lagging behind 4.04 tha ${ }^{-1}$ from the target (Fig. 1). The chronology of next priority areas for high yielding variety development and their target yield advantages in $\mathrm{t} \mathrm{ha}^{-1}$ are Saline Boro (4.03), Favourable Boro (long duration) (4.00), Cold-tolerant (Haor) (3.83), Tidal submergence (3.80), Healthier rice (Boro) (3.58), Favourable Boro (short duration) (3.33), Healthier rice (Aman) (3.30), Favourable Aman (3.23), Flash flood (3.09), Upland rice (2.89), Saline Aman (2.80), Healthier rice (Aus) (2.53), Premium quality rice (2.53), Drought (2.38), T.Aus (2.05) and deepwater. We already have surpassed the target in deepwater rice by $1.22 \mathrm{tha}^{-1}$ due to the development of BRRI dhan91 (Fig. 1).

Table 2. Potential rough rice yield (tha-1) of different rice types during 2015-2050.

\begin{tabular}{llllll}
\hline Rice types & 2015 & 2020 & 2030 & 2040 & 2050 \\
\hline Favourable Boro (short duration) & 6.69 & 7.16 & 8.13 & 9.14 & 10.33 \\
Favourable Boro (Long duration) & 7.81 & 8.60 & 9.77 & 10.99 & 12.42 \\
Saline Boro & 6.69 & 7.16 & 8.13 & 9.14 & 10.33 \\
Cold tolerant (Haor) & 6.69 & 7.16 & 8.13 & 9.14 & 10.33 \\
Cold tolerant (Northern and Western) & 6.50 & 6.95 & 7.90 & 8.88 & 10.04 \\
Healthier rice (Boro) & 6.91 & 7.39 & 8.40 & 9.45 & 10.68 \\
Favourable Aman & 6.30 & 6.74 & 7.66 & 8.61 & 9.73 \\
Saline Aman & 5.70 & 6.10 & 6.93 & 7.79 & 8.80 \\
Flash flood & 5.24 & 5.61 & 6.37 & 7.16 & 8.09 \\
Drought & 5.10 & 5.45 & 6.20 & 6.97 & 7.88 \\
Tidal submergence & 6.02 & 6.44 & 7.32 & 8.23 & 9.30 \\
Deepwater & 1.80 & 1.92 & 2.19 & 2.46 & 2.78 \\
Healthier rice (Aman) & 6.02 & 6.44 & 7.32 & 8.23 & 9.30 \\
Upland rice & 4.46 & 4.77 & 5.42 & 6.10 & 6.89 \\
T.Aus & 5.02 & 5.37 & 6.10 & 6.86 & 7.75 \\
Healthier rice (Aus) & 3.90 & 4.17 & 4.74 & 5.33 & 6.03 \\
Premium quality rice & 3.90 & 4.17 & 4.74 & 5.33 & 6.03 \\
Weighted average yield & 5.90 & 6.31 & 7.17 & 8.06 & 9.11 \\
National annual rice yield increase (\%) & - & 1.39 & 1.36 & 1.24 & 1.30 \\
\hline
\end{tabular}


Table 3. Rice yield target by 2050 versus progress made in Bangladesh by 2020 in rice types.

\begin{tabular}{|c|c|c|c|}
\hline Rice type & Highest yielding varieties by 2020 & $\begin{array}{c}\text { Potential } \\
\text { yield }\left(t \mathrm{th}^{-1}\right)\end{array}$ & $\begin{array}{l}\text { Target in } \\
2050\left(\mathrm{t} \mathrm{ha}^{-1}\right)\end{array}$ \\
\hline Favourable Boro (short duration) & $\begin{array}{l}\text { BRRI dhan81, BRRI dhan84, BRRI dhan86, } \\
\text { BRRI dhan88, BRRI dhan96, BRRI hybrid } \\
\text { dhan3, BRRI hybrid dhan5 }\end{array}$ & 7.00 & 10.33 \\
\hline Favourable Boro (Long duration) & BRRI dhan89, BRRI dhan92 & 8.42 & 12.42 \\
\hline Saline Boro & BRRI dhan 67 & 6.30 & 10.33 \\
\hline Cold tolerant (Haor) & BRRI dhan 45 & 6.50 & 10.33 \\
\hline $\begin{array}{l}\text { Cold tolerant (Northern and } \\
\text { Western) }\end{array}$ & BR18 & 6.00 & 10.04 \\
\hline Healthier rice (Boro) & BRRI dhan74 & 7.10 & 10.68 \\
\hline Favourable Aman & BRRI dhan87, BRRI hybrid dhan6 & 6.50 & 9.73 \\
\hline Saline Aman & BRRI dhan54 & 6.00 & 8.80 \\
\hline Flash flood & BRRI dhan52 & 5.00 & 8.09 \\
\hline Drought & BRRI dhan71 & 5.50 & 7.88 \\
\hline Tidal submergence & BRRI dhan44, BRRI dhan76 & 5.50 & 9.30 \\
\hline Deepwater & BRRI dhan91 & 4.00 & 2.78 \\
\hline Healthier rice (Aman) & BRRI dhan72 & 6.00 & 9.30 \\
\hline Upland rice & BRRI dhan83 & 4.00 & 6.89 \\
\hline T.Aus & BRRI dhan 48 , BRRI hybrid dhan7 & 5.70 & 7.75 \\
\hline Healthier rice (Aus) & BRRI dhan43 & 3.50 & 6.03 \\
\hline Premium quality rice & BRRI dhan34 & 3.50 & 6.03 \\
\hline
\end{tabular}

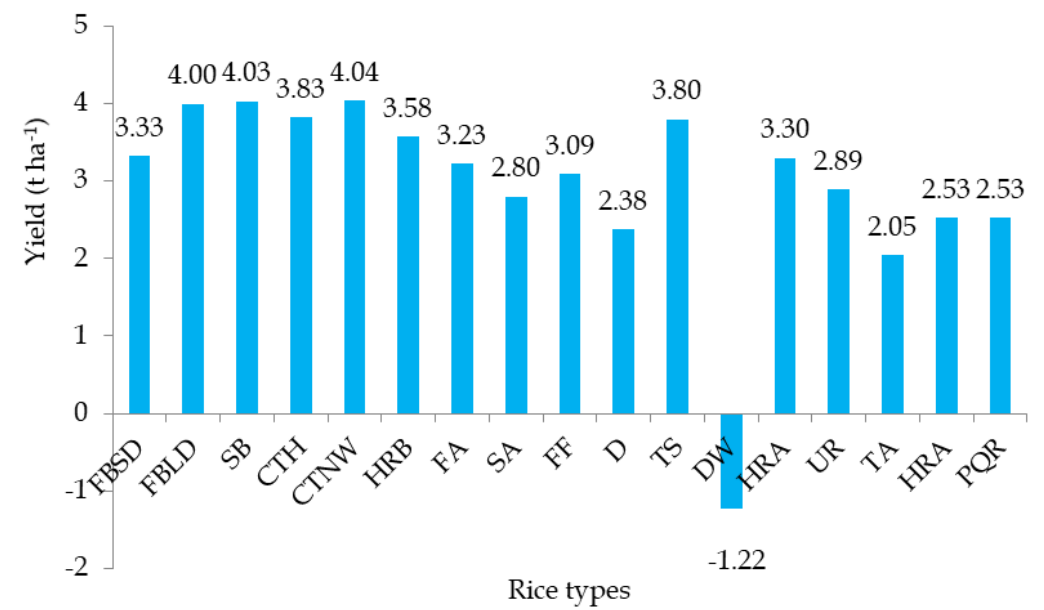

Fig. 1. Required yield improvement in rice types to meet the target by 2050.

Note: FBSD: Favourable Boro (Short Duration), FBLD: Favourable Boro (Long Duration), SB: Saline Boro, CTH: ColdTolerant (Haor), CTNW: Cold-Tolerant (Northern and Western), HRB: Healthier Rice (Boro), FA: Favourable Aman, SA: Saline Aman, FF: Flash Flood, D: Drought, TS: Tidal Submergence, DW: Deepwater, HRA: Healthier Rice (Aman), UR: Upland Rice, TA: T.Aus, HRA: Healthier Rice (Aus), PQR: Premium Quality Rice. 
Development and mapping the action plans for three decades on achieving target GYP

\section{Interventions for germplasm enhancement leading to increase the productivity}

Rice genetic resources are the most basic raw materials for the varietal improvement programs. A wider genetic base is very crucial for any improvement including production. This diversity comprises native landraces, local selections, elite/exotic cultivars, and wild relatives. The role of germplasm in the improvement of cultivated plants has been well recognized. A collection has little practical use if it has not been properly characterized/ evaluated and its attributes become known to breeders. Characterization includes receiving new samples, increasing these seeds, characterization and preliminary evaluation, and also more detailed evaluation and finally documentation.

BRRI Genebank has short, mid, and longterm storage facilities and the germplasm may be preserved safely for 50 to 100 years. Until now, 8604 germplasm have been registered and conserved in the Genebank, where around 5300 local landraces, 1400 pure lines, 1600 exotic indica, 100 japonica, and 46 wild species are available for utilization. Moreover, 90 wild rice samples were conserved in $e x$-situ type field conservation at BRRI net house.

Till 2018, a total of 907 germplasm were found moderate to highly resistant to different diseases and pests. Among those, 108 for blast, 76 for sheath blight, nine for stem rot, 638 for bacterial blight, one for bacterial leaf streak, two for bakanae, 13 rice tungro, and 52 for ufra diseases; 16 for $\mathrm{BPH}, 14$ for GLH, 33 for $\mathrm{WBPH}$, five for rice gall midge and seven for stem borer insects and 110 found tolerant against abiotic factors like submergence (20), tidal submergence (2), salinity (54), waterlogged condition (2), heat (15), cold (6) and drought (11). Besides 23 were found with long slender quality, 42 with a higher protein, 71 having anaerobic stress tolerant, three for good popping quality and 27 showed moderately allelopathic reaction (Table 4). Traditional rice varieties also possess outstanding characteristics such as aroma, grain and good cooking qualities, and tolerance to drought, flood, cold, salinity, and submergence. It is worth mentioning here that HabiganjBoro II, Hashikalmi, and Dular have a protein content of about $12 \%$ (Khalequzzaman et al., 2012; Nasiruddin and Bashar 1985).

Table 4. List of germplasm showing resistance/tolerance to different biotic, abiotic stresses and nutritional properties which may be used for doubling productivity (BRRI Annual reports of 1970-2018).

\begin{tabular}{|c|c|}
\hline Parameter & Germplasm \\
\hline Blast resistance & $\begin{array}{l}\text { Dular, Kataktara, DNJ-60, BR3, BR4, BR5, BR6, BR8, BR12, BR16, BR18, BR20, BR26, Shamraj, Malshira } \\
\text { (2) and Betu. Sixteen aromatic germplasm provided the lowest mean cluster disease score against blast } \\
\text { and also confirmed using molecular marker. }\end{array}$ \\
\hline $\begin{array}{l}\text { Sheath blight } \\
\text { resistance } \\
\text { (Moderate) }\end{array}$ & $\begin{array}{l}\text { Kataktara, Charnock, Sada pankaich, Katiksail, Chilknal, Gogragoira, Kalamanik, Hasa, Saria saita, } \\
\text { Kajalsail, Mogail balam, Absaya, Muktahar, Fulkaiz, Kalagura, Norio, Asmaita, Halud Jaron, Arali, } \\
\text { Hashful, Koia, Chinigura. Chotamona, Kuchi, Jotabashful, Kalamona, Kumragoir, Lohagor, Lotamona, } \\
\text { Dudhkalam, Kalajira, Kurchi magi, Arman sardar, Dudbazal and Murali. Forty genotypes were found } \\
\text { tolerant under supplemental irrigation conditions. }\end{array}$ \\
\hline Stem rot resistance & Beto, Ghigoj, Kataribhog, Mala J-15, Hashikalmi, Dular, Dharial, BR3 (tall) and BR9. \\
\hline $\begin{array}{l}\text { Bacterial blight } \\
\text { resistance }\end{array}$ & $\begin{array}{l}\text { Gabura, Khama, DV 85, Dhalikhama, Kachamota, Lalsidhurkouta, Bara bazal, Koiadigha, Laida, } \\
\text { Hashful, Hashumaita, Asmoita, Dilkhama, Lal khama, Kalagura, Chengamura, Chiknal, Kalo saita, } \\
\text { Kalosail, Gori bokri, Kahaia sundari, Hargaza, Ghunsi, Maloti, Akhnisail, Kalimekri 77-5, Ratasai } \\
\text { Dhona saita, Dholpata, Malbhog, Basmati (D), Sakkorkhora, Tulsimala, Balambiti Jessobalam TAPL-31, } \\
\text { Dholasaita, Dular, Hashikalmi, Chandina, Mala, BRI4. Ninety-six genotypes showed highly resistant to } \\
\text { bacterial blight (BB) showing the score of 1, } 35 \text { genotypes found moderately tolerant under } \\
\text { supplemental irrigation condition, } 125 \text { genotypes showed highly resistance to bacterial blight in } \\
\text { irrigated rice germplasm. }\end{array}$ \\
\hline
\end{tabular}


Table 4. Continued.

\begin{tabular}{|c|c|}
\hline Parameter & Germplasm \\
\hline $\begin{array}{l}\text { Bacterial leaf streak } \\
\text { resistance }\end{array}$ & Hashikalmi \\
\hline $\begin{array}{l}\text { Rice tungro virus } \\
\text { resistance }\end{array}$ & $\begin{array}{l}\text { Latisail, Kataribhog, SadaPankaissoloi, Hbj. Aman VIII, Badshabhog, TAPL-412, Tilockachari, } \\
\text { Tulsimanik, Lakshmijota, Badariota, Noroi, Jatramotor, Shirtwsail, Mi-Pajang. }\end{array}$ \\
\hline Ufra resistance & $\begin{array}{l}\text { Rayada 16-06-1, Sada Pankaich, Rayada 16-011, Rayada 16-013, Rayada 16-05, Rayada 16-06, Rayda 16- } \\
\text { 07, Rayada 16-08, Bazail, Fukuhunami, Hayakikari, Akiyutaka, Matsuhonami, Dhepi, Gabura, Hatisail, } \\
\text { Indrasail, Daudin, Kumari, Dudsar, Badsha bhogh, Lal aman, Jessobalam, Jhingasail, Khirai jail, } \\
\text { Nizersail, Patni-23, Rajasail, Sr-26b DA, Tilockachari, Lambosail, Kartiksail, Pankaij, Holidjaran, } \\
\text { Modhusail, Bhawalia aman, Lal chamara and Baish binni. }\end{array}$ \\
\hline Bakanae resistance & Panati, Nizersail (DA-25) \\
\hline $\begin{array}{l}\text { Green leaf hopper } \\
\text { resistance }\end{array}$ & $\begin{array}{l}\text { Jhingasail, Godalaki, Aswina, Dumai, Gadur, Hasmita, DNJ 97, Sailbinni, Ashajus, Golapi, Gabura, } \\
\text { Suna Digha(2), Dular, Khorma, Morium }\end{array}$ \\
\hline $\begin{array}{l}\text { Brown plant } \\
\text { hopper resistance }\end{array}$ & $\begin{array}{l}\text { Balam, Gotabazal, Bara bazal, Rajasail-21, Dudsar, Maliabhangor, Tangul, Krishnachura, Digha, } \\
\text { Sungwala }\end{array}$ \\
\hline $\begin{array}{l}\text { White backed plant } \\
\text { hopper resistance }\end{array}$ & $\begin{array}{l}\text { Khama 49/8, Laldhan, Begum bitchi, Khawrang, GiringNagpechi, Maitty chang, Boira aman, Kalaraj, } \\
\text { Malia bhangor, SR-26-B, Kawya, Bajal, Tara bali }\end{array}$ \\
\hline $\begin{array}{l}\text { Stemborer } \\
\text { Resistance }\end{array}$ & $\begin{array}{l}\text { Bhasamanik, Latisail, Raghusail Badshabhog, Patnai 23, DNJ 97, Joya, Botai, Kali boro, Kerani dhan, } \\
\text { Lembur, Tulsimala, Aghnisail, Rajasail, Chanmoni, Boilam, Lohargura, Murari, Jhoria }\end{array}$ \\
\hline $\begin{array}{l}\text { Gall midge } \\
\text { resistance }\end{array}$ & $\begin{array}{l}\text { OB 677, Vellutha cheera, Muktahar (acc 156), Safahar (acc 368) and Koha binni (acc 208) found } \\
\text { moderately resistant }\end{array}$ \\
\hline $\begin{array}{l}\text { Submergence } \\
\text { tolerance }\end{array}$ & $\begin{array}{l}\text { Soitedhora, Lohatang, Kumri, Kaliraj, Kaladhan, Hijaldigha, Sada gabura, Khoia motor, Kumragoir } \\
\text { and Ashfol. Acc. 4217, 4398, 4399, Kalojoma, DG1-349, Putidepa, Laldepa, Songa Tepi (Acc No. 4217), } \\
\text { Atshotti (Acc. No 4398), Muirol, Bhoban and Maityacheng found tolerant at seedling stage under } \\
\text { complete submergence. Pathornuti, Sadadangaboro, Jaldairri, Horkoach, Haloi, Bazal, Rajasail found } \\
\text { tolerant under medium water stagnation }\end{array}$ \\
\hline $\begin{array}{l}\text { Anaerobic } \\
\text { germination } \\
\text { tolerance }\end{array}$ & $\begin{array}{l}\text { Hatisail, Indrasail, Khirari, Joli, Lal aman, Nizersail, Ratasail, Halid jaran, Modhusail, Dharial, Chaita } \\
\text { Boro, D. Lia }\end{array}$ \\
\hline $\begin{array}{l}\text { Tidal submergence } \\
\text { Tolerance }\end{array}$ & Kumragoir, Dudmona \\
\hline $\begin{array}{l}\text { Salinity } \\
\text { tolerance }\end{array}$ & $\begin{array}{l}\text { Pokkali, Reyasail, Nonabokra, Uri dhan (Porteresia coarctata), Nonakochi, Sabrimaloti, BR23, Molla } \\
\text { digha, Bhawalia, Neppasha, Banoi jhak (3), Bawoi jhak (6), Kumri aman, Kolam, Lal kumari, Pura binni } \\
\text { (3), Sungwala, Lambra, Bazal dhan, Kala gura, Chand moni, Goda, Ghori aman, Binni dhan, Guda } \\
\text { aman, Boteswar, Begun bichi, Khama rang, Lembur, Lal bini, Halde mldi, Patnai, Latisail and Rajasail } \\
\text { were found tolerant against salinity. DWR genotype, Noakhali, Jota bhaulia and Kartiksail } 2 \text { were } \\
\text { found moderately tolerant at seedling stage. Lambra, Bazail dhan and Kechrail were found tolerant at } \\
\text { the reproductive stage. }\end{array}$ \\
\hline $\begin{array}{l}\text { Drought } \\
\text { tolerance }\end{array}$ & $\begin{array}{l}\text { Hashikalmi, Dular, Canthi bakla, N sail, Hashim, Urichedra, Goura kajol, Chini sail, Tall biruin, Sakkar } \\
\text { khana, Boaincha biruin }\end{array}$ \\
\hline $\begin{array}{l}\text { Heat } \\
\text { tolerance }\end{array}$ & $\begin{array}{l}\text { Acc. no. } 96,97,100,128,131,133,563,568,816,1212,1532,1546 \text { and } 1688 \text { under net house and acc. no. } \\
104 \text { at field conditions found best tolerant to heat. }\end{array}$ \\
\hline $\begin{array}{l}\text { Cold } \\
\text { Tolerance }\end{array}$ & $\begin{array}{l}\text { Acc. no. } 114 \text {, acc. no. } 177 \text {, acc. no. } 197 \text { and acc. no. } 202 \text { and } 472 \text { were found best tolerant to cold. Bhutan (a } \\
\text { Bhutanese germplasm) showed better tolerance against cold for both seedling and reproductive stage. }\end{array}$ \\
\hline Allelopathy & $\begin{array}{l}\text { Kataribhogh, Kartiksail, Jhingasail, Burikatari, Bolorum, Chakulia, Shadadumra, Kola dama, Joli, } \\
\text { Rangpuri(sada), Mi-chocho, Biruin (Tola), Balamdhan, Rajasail }\end{array}$ \\
\hline High protein & $\begin{array}{l}\text { BR5, Baha bhogh, Thakurbhogh, Habiganj Boro II, Hashikalmi, Dular, Ashfol, Birani dhan, Horkoch, } \\
\text { Kachra, Jira dhan, IR 1010, Laltupi, Joyosri ghunshi, Banajira, Dhala saita, Hashikalmi, Kartikjhul, Holid } \\
\text { jaran, Apchaya, Jamaibhog, Arichadigha, Manik digha 1, Goirol, Bashful, Bawoijhak 4, Bawoijhak 6, } \\
\text { MI-Pajang, Chakil, Lema, Niamat, Magoibalam, Matichak, Neda, Molladigha and Boilam. }\end{array}$ \\
\hline Popping quality & Highest percentage of popping were found in Kanakchul, Nizersail and Rangabinni \\
\hline $\begin{array}{l}\text { Zn enriched } \\
\text { (aromatic) }\end{array}$ & Sagardhana, Nunia, Binaphul, Begun bitchi, Hatisail, Sakkorkhana, Kalobakri \\
\hline
\end{tabular}


Important points for efficient utilization of rice germplasm

- The collection of germplasm from home and abroad needs to be continued to enrich the Genebank with more diversity.

- Characterization and evaluation of all of the germplasm should be carried out against the major yield contributing traits and for biotic/abiotic stresses (cold, heat, flood, drought, submergence, water stagnancy, salinity, blast, etc.) and/or grain quality through the morphological and molecular tools. Phenomics should be playing a key role in the characterization of germplasm. All the germplasm accessions should also be fingerprinted with genome-wide highdensity markers. These are also needed for duplicate sorting, the establishment of Intellectual property rights and to protect germplasm from biopiracy.

- Developing new varieties from landraces through Pure Line Selection like BR5 and BRRI dhan34.

- The development of pre-breeding materials is a very important task for the Genebank team. "Pre-breeding" is the initial phase of any breeding programme utilizing germplasm.

- QTL identification for different traits and partial/whole-genome sequencing is important for germplasm/Geographical Indication (GI) rice which will be used for the crossing programme. Genome-wide association mapping may be used for the QTL identification from sequencing data which is proven very effective for rice germplasm.

- Development of a biodiversity park where all of the germplasm needs to be grown in respective season over the years and kept open to rice breeders for the necessary selection of pre-breeding materials.

- Documentation of characterized/evaluated germplasm through digital photo and computer database documentation system through appropriate software for different users. From this database, one can retrieve the germplasm with the targeted trait(s) very easily.

- Core collections (a representative sample of the alleles from the entire collection) serve as an entry point to the whole collection and improve the access of the plant breeder, researcher, geneticists, and other users to the germplasm collection.

- Genebank may serve the raw materials for C4 rice development.

- Wild rice may be used for crossing to break the yield ceiling as these are the vast reservoir of beneficial genes and have higher genetic diversity than cultivated rice.

- Development of several Breeding Hub for developing location-specific rice variety by utilizing materials from Genebank.

- Easy supply/exchange of rice germplasm to national/international researchers/ organizations at home and abroad for efficient utilization.

Genebank is reservoir of genes, used in plant breeding. Effective use of genebank in breeding relies on a thorough understanding of the existing genetic diversity and knowledge of the genes present in individual accessions. Knowledge gained through the activities of characterization and evaluation could be used in rice breeding for developing improved rice variety which will ultimately meet the increasing food demand of the country.

\section{Plant breeding interventions}

For developing further high yielding varieties by breaking yield ceiling, BRRI breeding programs have undertaken several modernization activities leading to accelerated genetic gain as follows:

Increasing selection efficiency. Selection efficiency of BRRI breeding programmes has been increased through increasing the size of breeding programs with the application of single-seed-descent based rapid generation advancing (RGA) technique and wide-scale 
application of high throughput molecular markers.

Currently, BRRI breeding programmes are advancing around 1.5 million segregating progenies per year utilizing both greenhouse and field rapid generation advance (RGA) techniques. More or less all breeding programs, including favourable and unfavourable breeding programmes have been transformed from an inefficient and slow pedigree method of breeding towards single seed descent (SSD) based RGA technique enabling two to three generations per year. So far, around 1,26,855 fixed lines have been generated and evaluated in line stage testing (LST) from these segregating progenies. Accelerated breeding cycles will hopefully contribute to achieving desired genetic gain with respect to grain yield, quality, and stress resistance traits in a shorter period of time.

High throughput molecular markers are playing a key role in increasing the selection efficiency of BRRI breeding programs. Low density and high-density molecular markers are routinely being utilized in the breeding programs (Table 5) in a number of interventions like quality checking of parental lines and $\mathrm{F}_{1}$ 's using 10-SNP (Single nucleotide polymorphism marker) indica panel, QTL (quantitative trait loci) finger-printing of the parental lines using trait-based SNPs, GBS (genotyping by sequencing) profiling of the parental lines for the determination of sequence-based genetic distance and deploying trait-based SNPs at LST trials (Table 5). So far, QTL fingerprinting has been done for 835 parental genotypes with traitbased SNPs. Confirmation of 8,56,676 F's has been done using 10-SNP QC (quality control) panel. GBS profiling has been done for 450 parental genotypes with diversity array technology based sequencing (DArT-Seq) SNPs. QTL fingerprinting data and GBS profiles have been utilized to generate distance matrix in all possible combinations from which high-value elite-by-elite crosses have been accomplished. Around 2,604 genotypes have been assayed with 1k-Rice Custom Amplicon (1k-RiCA) panel and genetic sequence-based breeding values of parental lines have been calculated. Around 29,582 LST lines have been genotyped with key diagnostic SNP markers for tracking useful oligogenic traits conferring different biotic and abiotic stress tolerances and grain quality traits. In the future, BRRI breeding programs will put more focus on the utilization of bioinformatics tools for increasing selection efficiency like genomic selection and selection of potential parents and high-value cross-combinations based on sequence data (Table 5).

Increasing selection intensity. Enlarged breeding programs and wide-scale application of high throughput molecular markers are also contributing to increased selection efficiency in BRRI breeding programs. Selection intensity has also been increased through ensuring a large number of early generation breeding lines entering into multi-environmental yield trials. Around 3500 breeding lines in Observational Yield Trials (OYT) are being evaluated every year in at least three locations.

Increasing selection accuracy. Selection accuracy of BRRI breeding programs has been increased through product profile-based breeding, automation in post-harvest operation, digitalization in data collection, and management, following appropriate experimental design and analysis, ensuring large plot size with replicated trials, increasing number of multi-location trials and appropriate field and post-harvest management (Table 5). BRRI breeding programs are now utilizing Breeding for Results (B4R) software for the integrated data management system. In the case of automation, electronic scale-like Phenoapp, digital weighing-cum-moisture recording device harvest-master, digital seed counting 
device like Seed Analyzer, non-destructive grain quality data recording device like near infra-red (NIR) analyzer, etc. are being utilized for handling large breeding population. Earlier, breeding lines constituting in regional yield trial (RYT) would have been tested in multi-locations but nowadays multienvironment trial (MET) has been initiated starting from OYT which is efficiently contributing towards increased selection intensity from large breeding trials. Product profiles are a complete set of characters to be present in target varieties for a particular geographical segment. BRRI has developed sixteen product profiles through surveying different value chain actors. Product profiles are contributing to the selection of parents, selection of high-value cross combinations, and the promotional decision of breeding lines from one stage to another. As a whole product profile-based breeding is contributing to increased selection accuracy of breeding programmes.

Cyclic breeding for accumulating yield contributing genes/alleles in the same genetic background. Currently, population improvement is the key concept of BRRI breeding programs. BRRI has started recycling early generation breeding lines with higher breeding values in crossing programs. While crossing between two parents, sequence-based genetic distances are being considered. As per the current concept, around $65 \%$ of the rice genes are responsible for grain yield. Like grain yield, plant types are also highly polygenic characters. Hopefully, this recurrent selection through cyclic breeding will contribute to developing high yielding inbred rice varieties to produce enough for the increased population by 2050 .

\section{Interventions with biotechnological tools}

Utilizing biotechnological tools, BRRI so far has released several rice varieties such as BRRI dhan52, BRRI dhan58, BRRI dhan79, BRRI dhan86, BRRI dhan87, BRRI dhan89, BRRI dhan92, and BRRI dhan96 which are high yielding along with possessing special characteristics. BRRI's capability concerning the application of biotechnological tools in variety development has got momentum with these successes. BRRI has utilized quantitative trait loci (QTL) study, marker-assisted selection (MAS), somaclonal variation, and anther culture techniques to develop the aforementioned varieties (Table 5). Also, BRRI is practicing other biotechnological tools and adopting newer techniques sharply in this domain. However, the Biotechnology division of BRRI already has developed advanced breeding lines containing bacterial blight resistance genes like $\mathrm{X} a 4, x a 13$, and Xa21. This division has cloned the vacuolar ATPase (PVA) gene from Porteresia coarctata and developed the construction with Agrobacterium LBA4404 which will confer salinity tolerance upon transformation into the rice. Also, this division has developed putative T1 transgenic plants containing salt tolerance GlyI and GlyII gene (Glyoxalase I and Glyoxalase II). Besides, this division is trying to introgress salt tolerance gene AeMDHAR (Monodehydroascorbate reductase) into BRRI rice varieties. Other priority areas of this division are developing high yielding aromatic, low glycemic index, antioxidant-enriched, and $\mathrm{C} 4$ rice development. However, it is more likely that timely harnessing the biotechnological tools would support conventional breeding for efficiently improving rice yield and quality along with biotic and abiotic stress tolerance. With this light, this part of the article will discuss briefly how some of the key biotechnological tools can be utilized more efficiently in the future for increasing productivity. However, we will categorize the biotechnological tools in the following three broader areas.

Marker Assisted Selection (MAS). Molecular markers bring crop diversity in breeding programs which largely track desired 
genes of interest limiting associated linkage drag. A recent study revealed that only half out of sixty well-validated genes and QTLs for disease resistance, grain quality, and abiotic stress were present in 75 elite indica rice varieties paves a huge research opportunity using MAS to explore (Cobb et al., 2019). But this tool is very effective only when there is an oligogenic trait (Amiri Fahliani et al., 2011). A polygenic trait showing continuous variations should not be a choice for MAS. Therefore, to carry out a successful MAS, identification of a major gene or development of robust QTL is very crucial. Transcriptomics technologies could be applied for target gene identification. For identifying QTLs, genome-wide association mapping explores more diversity and has higher cost-effectiveness than biparental QTL mapping (Verdeprado et al., 2018). Also, association mapping can track the presence or absence of a gene in a broader genetic context (Cobb et al., 2019). QTL studies often reveal a complex trait without having any major regulating genes could be a choice for genomic selection (GS) where small effect Favourable alleles could be accumulated for desired improvement (Cobb et al., 2019). GS establishes an association between genomewide markers and phenotypes. It estimates individual loci value and eventually predicts the genetic value of an untested population (Wang et al., 2018).

Tissue culture. Among tissue culture techniques, anther culture poses to be very effective allowing immediate fixation of homozygosity through diploidization often by spontaneous chromosome doubling (Ruwani et al., 2018). Whereas, embryo rescue, another potential tissue culture technique, can successfully grow the plants achieved from intervarietal, interspecific and intergeneric, or more distantly related crosses and bring novel genetic material and traits in breeding programs. These crosses could otherwise generate abortive embryos (Kausch et al.,
2016). Traits having limited or no natural variation eg. sheath blight resistance in rice can be created using somaclonal variation (SV) which induces genetic or epigenetic changes in plant cells and tissues during culture. These induced variations can be utilized if found beneficial (Anil et al., 2018).

Genetic transformation. Genetic engineering is one of the key biotechnological tools that allows transferring novel traits to rice from evolutionary distant plants, even from fungi, viruses, bacteria, and animals. It is being used world-wide including in Bangladesh to make rice plant stress-tolerant and nutritionally enriched. Among a number of DNA delivery methods available, Agrobacterium and biolistic mediated transformation remain pivotal (Sahet al., 2014). However, genetically transformed rice varieties are more likely to take a longer period of time to get released due to its foreign DNA and subsequent lengthy and stringent biosafety regulations. Genome editing is giving hope to ease up the regulation since foreign DNA will be excluded from the host genome. CRISPR/Cas9, among a variety of genome editing tools, claims maximum acceptance due to its accuracy, simplicity, and robustness (Mishra et al., 2018). We have already started genome editing interventions through CRISPR/Cas9 technique for the development of highyielding aromatic, blast-resistant, and $\mathrm{BPH}$ resistant rice varieties.

\section{Hybrid rice breeding interventions}

Hybrid rice technology is among the greatest innovation, which can increase productivity readily upon being adopted. It has at least 15$20 \%$ higher yield potential compared to high yielding inbred rice varieties using the same inputs. Hybrid rice varieties have proved the ability to perform better under unFavourable conditions in varying environments like drought, cold and saline conditions (Singh et al., 
2009). Furthermore, this technology increases farm incomes and stabilized grain prices for consumers (Spielman et al., 2012). Hybrid rice plays one of the key components of food security, especially in poor countries in the tropics, where the population is increasing rapidly, and eventually, the cultivable land is decreasing (Santiaguel and Quipot, 2012). Hybrid rice greatly contributed to boosting rice production in China (Spielman et al., 2012). This technology has attracted the attention of research leaders and policy-makers in many Asian countries for breaking the yield ceiling in rice production (Hossain et al., 2003). The 'father of hybrid rice', professor Longping Yuan mentioned that Bangladesh could be selfsufficient in food grains through the adoption of hybrid rice technology (Yuan, 2012).

Hybrid rice research and development program has been undertaken since the last couple of decades at BRRI with technical support from the International Rice Research Institute (IRRI) and financial support from Bangladesh Agricultural Research Council (BARC) aimed to meet the extra food for the growing population of the country (Rashid et al., 2011). Meanwhile, BRRI developed seven hybrid rice varieties, of which four varieties for Boro and two varieties for Transplanting Aman (T. Aman), and one variety for Transplanted Aus (T. Aus) season. The average yield potentiality of Boro hybrid rice varieties is more than $9.0 \mathrm{t} \mathrm{ha}^{-1}$ whereas T. Aman hybrid rice varieties give more than $6.5 \mathrm{t} \mathrm{ha}^{-1}$. The only released T. Aus hybrid rice variety from BRRI has a yield potential of $6.5 \mathrm{t} \mathrm{ha}^{-1}$.

To date, almost all of the registered hybrid rice including BRRI hybrids are suitable for Favourable rice type ecosystems (SCA, 2020). Therefore, more emphasis is needed to develop climate-smart rice hybrids for meeting the uprising food demand of the nation. If it is not possible to develop rice hybrids tolerant in stress-prone environments /ecosystems within 2030, then we can expand hybrid rice cultivation areas. It is observed that four specific rice types such as Favourable Boro (short duration), Favourable Aman, Upland rice, and T.Aus rice types are suitable for hybrid rice intensification (Table 3). The yield gap for Favourable Boro (short duration), can be minimized by utilizing hybrid rice varieties especially BRRI hybrid dhan3 and BRRI hybrid dhan5. We need to further increase hybrid rice cultivation in Favourable Boro (short duration) rice type by $36.5 \%$ to fulfill the yield gap. Likewise, the yield gap during favourable Aman season can be nullified byadditionally increasing the cultivation of BRRI hybrid dhan4 and BRRI hybrid dhan 6 by $30 \%$. Cultivation of BRRI hybrid dhan7 can be further increased by $30 \%$ in the upland rice and $36.8 \%$ in T. Aus area to reach the target yield by 2030 (Table 3).

Hybrid rice technology is the specialized approach compared to inbred rice technology which needs a sufficient number of skilled manpower to conduct research and development, seed production, promotion, and dissemination activities properly. More expert personnel and associates are needed under the Hybrid rice research division of BRRI to conduct hybrid rice research and development activities as per the demand of stakeholders.

The development of new hybrid varieties for changing agro-climatic conditions can accelerate productivity. Developing new hybrid varieties with high yield potential needs to employ several breeding practices for changing ideotypes and exploiting maximum heterosis. Super high yielding hybrid rice varieties could be developed through, 1) increasing plant biomass through increasing plant height from semi to tall and then tall to super tall for the yield increase of 12 to 14 , and then further to $18 \mathrm{t} \mathrm{ha-}^{-1}$, respectively; 2) Developing highly photosynthetic efficient 
plant population by morphological improvement; 3) exploring more heterosis from indica/japonica combination and favourable genes/QTLs to enhance lodging tolerance; and, 4) improving harvest index to 0.50-0.55 (Ma and Yuan, 2015). The hybrid rice group of BRRI has set the target to develop hybrid rice varieties having at least $2 \mathrm{t}$ ha- $^{-1}$ yield advantage over the existing best varieties along with better grain qualities. Doing so, the existing hybrid rice research facility of BRRI should be strengthened to contribute to the future food security of the country.
It is a tremendous task to fulfill the targeted demand. It needs to develop a well-trained target group for developing and multiplying parental lines, hybrid rice seed production, processing, storing, and marketing. Therefore, to meet the demand, BRRI should take initiative to strengthen hybrid research and collaborate with the public and private entrepreneurs at the national and international levels. BRRI needs to establish a well-equipped Hybrid Rice Research Center like China and the Philippines, which could help to develop a skilled group to take over the future challenges (Table 5).

Table 5. Mapping the action plans for achieving the target GYP for three decades.

\begin{tabular}{|c|c|c|c|}
\hline Program & $2021-2030$ & $2031-2040$ & $2041-2050$ \\
\hline \multicolumn{4}{|l|}{ Application of population improvement strategy for accelerated genetic gain. } \\
\hline \multicolumn{4}{|l|}{ Application of molecular marker assisted selection } \\
\hline \multicolumn{4}{|l|}{ Application of QTL fingerprinting and GBS profiling } \\
\hline \multicolumn{4}{|l|}{ Development of genomic selection } \\
\hline \multicolumn{4}{|l|}{ Application of genomic selection } \\
\hline \multicolumn{4}{|l|}{$\begin{array}{l}\text { Enhanced automation and digitalization in genotypic and phenotypic data } \\
\text { management }\end{array}$} \\
\hline \multicolumn{4}{|l|}{$\begin{array}{l}\text { Utilizing phenotypic automation and digitalization in genotypic and pheno- } \\
\text { typic data management }\end{array}$} \\
\hline \multicolumn{4}{|l|}{$\begin{array}{l}\text { Development and utilization of modern seed processing, storage and breed- } \\
\text { ing germplasm management system }\end{array}$} \\
\hline \multicolumn{4}{|l|}{ Utilization of anther culture, somaclonal variation and embryo rescue } \\
\hline \multicolumn{4}{|l|}{ Enhancement of genetic engineering and genome editing facility } \\
\hline \multicolumn{4}{|l|}{ Utilization of genome editing and genetic engineering } \\
\hline \multicolumn{4}{|l|}{ Enhancement of OMICS facilities } \\
\hline \multicolumn{4}{|l|}{ Utilization of OMICS } \\
\hline Increasing hybrid rice seed growers for enhanced adaptation & 150 & 300 & 500 \\
\hline \multicolumn{4}{|l|}{ Establishment of molecular laboratory for hybrid rice development } \\
\hline \multicolumn{4}{|l|}{ Application of molecular techniques in hybrid rice development } \\
\hline \multicolumn{4}{|l|}{$\begin{array}{l}\text { Enhancement of seed processing and storing facilities for hybrid rice devel- } \\
\text { opment }\end{array}$} \\
\hline \multicolumn{4}{|l|}{$\begin{array}{l}\text { Modernization of existing genebank and establishment of an underground } \\
\text { genebank }\end{array}$} \\
\hline \multicolumn{4}{|l|}{$\begin{array}{l}\text { Development of rice germplasm characterization/ evaluation facilities (Net } \\
\text { house/ Phytotron) }\end{array}$} \\
\hline \multicolumn{4}{|l|}{ Complete/ partial sequencing of 5300 native germplasm } \\
\hline \multicolumn{4}{|l|}{$\begin{array}{l}\text { Digitalization of genebank management system (software/ website for gene- } \\
\text { bank database development) }\end{array}$} \\
\hline Manpower development & & & \\
\hline
\end{tabular}




\section{CONCLUSIONS}

We fragmented rice areas of Bangladesh into 17 different rice types based on different rice ecosystems and pressing needs and set different targets for each, so that, combinedly we can reach an average rough rice yield target of 9.11 tha $^{-1}$ by 2050 . We compared the yield targets by 2050 and the yield of topyielding rice varieties in Bangladesh by 2020 across the rice types to understand the current position of our varietal improvement programs. Eventually, we sorted out how much improvement is needed in each rice type which will be implemented in varietal development programs of the country in the coming years. BRRI, the leading institute for rice research in the country which so far has released 106 inbred and hybrid rice varieties will further accelerate its breeding programs through combined genetic interventions like population improvement through cyclic breeding and high throughput molecular markers, bioinformatics, genome editing, genetic transformation, germplasm utilization through genome-wide molecular markers and phenomics and development of super hybrid rice. There are specific scopes of increasing the yield potential of rice varieties for cold-tolerant (Northern and western), Saline Boro, Favourable Boro (long duration), etc. Addressing the challenges with combined genetic interventions, BRRI will achieve yield targets in all respective areas by 2050 .

\section{RECOMMENDATION}

A combination of available genetic interventions like population improvement through cyclic breeding, genomic selection, marker-assisted selection, genome editing, genetic transformation, germplasm utilization through genome-wide association study and phenomics, and development of super hybrid rice is the only option for achieving target GYP by 2050.

\section{ACKNOWLEDGEMENTS}

The authors wish to thank anonymous reviewers for their suggestions, which significantly improved this article.

\section{AUTHORS' CONTRIBUTION}

SMHAR generated idea; SMHAR, PLB, ESMHR and KMI coordinated the research; SMHAR, KMI and MUS developed methodology; MSR and MSK provided scientific insights; SMHAR, KMI, NMFR and MARS gathered data; NMFR and MAAM carried out analysis and synthesis; SMHAR, PLB, ESMHR and KMI did the writings for all versions of the manuscript; MSR and MARS performed critical review and editing; All authors read and approved the final manuscript.

\section{DECLARATION OF INTERESTS}

A version of the paper was published in a book "Doubling Rice Productivity in Bangladesh" in 2020 by the Bangladesh Rice Research Institute (BRRI), Gazipur 1701, Bangladesh to commemorate BRRI's $50^{\text {th }}$ anniversary. The Bangladesh Rice Journal has prior knowledge of the book publication and does not see any conflict of interest.

\section{REFERENCES}

Amiri, F R, M Khodambashi, S Houshmand, A Arzani and K Sorkheh. 2011. Heritability for Some Agronomic Characters of Rice (Oryza Sativa L.) and Their Linked Microsatellites Identification. Turkish Journal of Agriculture and Forestry, 35 (5): 481-90. DOI: 10.3906/tar-1001-645.

Anil, V, S Lobo and S Bennur. 2018. Somaclonal Variations for Crop Improvement: Selection for Disease Resistant Variants in Vitro. Plant Science Today, 5 (2): 44-54. DOI: 10.14719/pst.2018.5.2.382.

BBS (Bangladesh Bureau of Statistics). 2018. Statistical Yearbook of Bangladesh 201. Bangladesh Bureau of Statistics, Statistics and Informatics Division, Ministry of Planning, Government of the People's Republic of Bangladesh, Dhaka, Bangladesh.

Cobb, J N, P S Biswas and J D Platten. 2019. Back to the Future: Revisiting MAS as a Tool for Modern Plant Breeding. Theoretical and Applied Genetics, 132 (3): 647-67. DOI: 10.1007/s00122-018-3266-4. 
Hossain, M, A Janaiah and M Husain. 2003. Hybrid Rice in Bangladesh: Farm-Level Performance. Economic and Political Weekly, 38 (25): 2517-2522.

Iftekharuddaula, K M, M A Newaz, M A Salam, H U Ahmed, A A Mahbub, E M Septiningsih, B C Y Collard, D L Sanchez, A M Pamplona and D J Mackill. 2011. Rapid and high-precision marker assisted backcrossing to introgress the SUB1 QTL into BR11, the rainfed lowland rice mega variety of Bangladesh. Euphytica, 178: 83-97.

Kabir, M S, M U Salam, A K M S Islam, M A R Sarkar, M A A Mamun, M C Rahman, B Nessa, M J Kabir, H B Shozib, M B Hossain, A Chowdhury, M Nasim, K M Iftekharuddaula, M S Hossain, M K A Bhuiyan, B Karmakar, M S Rahman, M M Haque, M T Khatun, M P Ali, S M H A Rabbi, P L Biswas, E S M H Rashid and N M F Rahman. 2020. Doubling rice productivity in Bangladesh: A way to achieving SDG 2 and moving forward. Bangladesh Rice Journal, 24 (2): 1-47.

Kabir, M S, M U Salam, A Chowdhury, N M F Rahman, K M Iftekharuddaula, M S Rahman, M H Rashid, S S Dipti, A Islam, M A Latif, A K M S Islam, M M Hossain, B Nessa, T H Ansari, M A Ali and J K Biswas. 2015. Rice Vision for Bangladesh: 2050 and Beyond. Bangladesh Rice J., 19 (2): 1-18.

Karim, Z, S G Hussain and M Ahmed. 1990. Salinity Problems and crop intensification in the coastal regions of Bangladesh. Soils publication no. 8, Bangladesh Agricultural Research Council, Farmgate, Dhaka-1215, Bangladesh, 1-63.

Kausch, A P, M Tilelli, J Hague, C Heffelfinger, D Cunha, M Moreno, S L Dellaporta and K Nelson. 2016. In Situ Embryo Rescue for Generation of Wide Intraand Interspecific Hybrids of Panicum virgatum L. Plant Biotechnology Journal, 14(11): 2168-75. DOI: 10.1111/pbi.12573.

Khalequzzaman, M, M A Siddique and M K Bashar. 2012. Rice Genetic Resources Conservation and Utilization in Bangladesh. Proceedings of National Workshop on Plant Genetic Resources for Nutritional Food Security held at BARC, Dhaka, Bangladesh.

Ma, G H and L P Yuan. 2015. Hybrid Rice Achievements, Development and Prospect in China. Journal of Integrative Agriculture, 14 (2): 197-205.

Mishra, R, R K Joshi and K Zhao. 2018. Genome Editing in Rice: Recent Advances, Challenges, and Future Implications. Frontiers in Plant Science, 9. DOI: 10.3389/fpls.2018.01361.

Nasiruddin, M and M K Bashar. 1985. Conservation of rice germplasm in Bangladesh: Ten years of Agricultural Research in Bangladesh. Proceedings of the National Symposium of Agril Res., BARC, Dhaka, Bangladesh.

Pandey, P R and H Bhandari (eds.). 2018. Rice Technological Innovation and Value Chain Development in South Asia:
Current Status and Future Directions: SAARC Agriculture Centre, p. 164.

Rashid, H A, A W Julfiquar and S Ali. 2011. History, Impact and Current Status of Hybrid Rice Research, Development and Delivery in Bangladesh. Dhaka, Bangladesh. Policy Brief, Agricultural Advisory Society. Available at: http://aas-bd.org/wpcontent/uploads/2018/01/ii-A-study-on-hybridrice-in-BangladeshHistory-impact-and-currentstatus-of-hybrid-rice-research-development-anddelivery-in-Bangladesh-2011.pdf (accessed on March 14, 2021).

Ruwani, G M, D Mayakaduwa and T D Silva. 2018. Anther Culture as a Supplementary Tool for Rice Breeding. In: Intech Open (Open Accessbook). DOI: 10.5772/intechopen. 76157

Sah, S, K A Kaur, G Kaur and G Cheema. 2014. Genetic Transformation of Rice: Problems, Progress and Prospects. Rice Research:Open Access, 03 (01). DOI: 10.4172/2375-4338.1000132

Santiaguel, A F and L M Quipot. 2012. Hybrids Head for the Tropics. Rice Today. Published on July 1, 2021. Available at: https://ricetoday.irri.org/hybridshead-for-the-tropics/ (accessed on March 14, 2021).

SCA (Seed Certification Agency). 2020. Ministry of Agriculture, Government of the People's Republic of Bangladesh, Gazipur, Bangladesh. Available at: http://www.sca.gov.bd/site/files/7dee0533-035c49a2-98ed-4f69f7df44f7/-(accessed on October 14, 2020).

Singh, A K, B Kumar, R S Baghel and R B Singh. 2009. Sustainability of Hybrid Rice Technology vis a vis Inbred Rice in Uttar Pradesh. Indian Res. J Ext. Edu., 9 (2): 22-25.

Spielman, D, D Kolady, P Ward, H Rashid and K Gulati. 2012. Public Expenditures, Private Incentives, and Technology Adoption: The Economics of Hybrid Rice in South Asia. IFPRI discussion paper 01233. Environment and Production Technology Division.

Verdeprado, H, T Kretzschmar, H Begum, C Raghavan, P Joyce, P Lakshmanan, J N Cobb and B C Y Collard. 2018. Association Mapping in Rice: Basic Concepts and Perspectives for Molecular Breeding. Plant Production Science, 21 (3): 159-76. DOI: 10.1080/1343943X.2018.1483205.

Wang, X, Y Xu, Z Hu and C Xu. 2018. Genomic Selection Methods for Crop Improvement. Current Status and Prospects. Crop Journal, 6 (4): 330-40. DOI: 10.1016/j.cj.2018. 03.001.

Yuan, L. 2012. Q and A with the Father of Hybrid Rice.Rice Today, Published on July 19, 2012. Available at: https:/ / ricetoday.irri.org/qa-with-thefather-of-hybrid-rice/ (accessed on March 14, 2021). 